\title{
Do Brazilian Pregnant Women Need lodine Supplementation? A Commentary on the Latest American Thyroid Association Guideline
}

\author{
Gestantes brasileiras precisam de suplementação de iodo? Comentário \\ sobre a mais recente diretriz da Associação Americana de Tireoide
}

\author{
Mateus Dornelles Severo ${ }^{1}$ Rafael Selbach Scheffel ${ }^{2}$ \\ 1 Universidade Federal de Santa Maria, Santa Maria, RS, Brazil \\ 2 Universidade Federal do Rio Grande do Sul, Porto Alegre, RS, Brazil
}

Rev Bras Ginecol Obstet 2018;40:1-3.

Iodine is an essential micronutrient required for the production of thyroid hormones, which are critical for homeostasis and neurodevelopment. Because of increased thyroid hormone production, renal iodine excretion and fetal iodine requirements, dietary iodine requirements are higher in pregnancy than they are for nonpregnant adults. ${ }^{1}$ Based on this, the World Health Organization (WHO) and the American Thyroid Association (ATA) recommend a daily iodine intake of $250 \mu \mathrm{g}$ for pregnant and lactating women., Iodine deficiency disorder (IDD) in pregnant women could result in harmful effects, including goiter, cretinism, hypothyroidism, growth retardation, pregnancy loss, and infant mortality. Moreover, inadequate iodine intake during pregnancy may lead to neurodevelopmental deficits in offspring, and iodine deficiency is currently considered the leading preventable cause of intellectual impairment worldwide. ${ }^{4}$ On the other hand, the excess of iodine may result in fetal goiter and hypothyroidism. Exposures as minor as the vaginal application of povidone-iodine during delivery or local use of disinfectant in newborns can lead to increased serum TSH concentrations ${ }^{5}$ and transient neonatal hypothyroidism. ${ }^{6}$

With this information in mind, we read with great interest the 2017 Guidelines of the American Thyroid Association for the Diagnosis and Management of Thyroid Disease during Pregnancy and the Postpartum. ${ }^{7}$ Among other topics, the nutritional aspects related to iodine sufficiency are addressed in section IV, and a supplementation with $150 \mu \mathrm{g}$ of potassium iodine per day is suggested on Recommendation 6 for women, in most regions of the world, who are planning a pregnancy or currently pregnant. This is optimally started 3 months in advance of planned pregnancy (strong recommendation, moderate-quality evidence). Could this recommendation improve the quality of the prenatal care of Brazilian pregnant women?

The most efficient method of IDD prevention is salt iodination. Also, ongoing monitoring of population biomarkers, such as urinary iodine concentration, is essential to ensure that population iodine intakes are optimized. In Brazil, the salt iodination is controlled by federal law in partnership with the National Agency for Sanitary Surveillance (Anvisa, in the Portuguese acronym) and the salt productive sector. ${ }^{8-10}$ Unfortunately, data on the iodine nutritional status are scarce and contradictory in Brazil. The national project of salt iodination (PNAIsal, in the Portuguese acronym) (which evaluated 477 locations and a total of 18,978 school children) identified Brazil as a country of "more than appropriate" iodine consumption, with a mean urinary iodine excretion (UIE) concentration of $276 \mu \mathrm{g} / \mathrm{L} .{ }^{11,12} \mathrm{~A}$ recent meta-analysis concluded that the majority of the data on this subject are derived from the population in the south/southeast region of Brazil, but the actual overall IDD prevalence is unknown and might still be high in some areas. ${ }^{13}$

Regarding the pregnant population, three studies were published prior to Anvisa's decision to reduce the salt iodine concentration. In the first one, Barca and cols studied 20 pregnant women and showed a median UIE of $167.8 \mu \mathrm{g} / \mathrm{L}$. $^{14}$ The second study evaluated a larger sample (147 women) and observed median UIE of $224 \mu \mathrm{g} / \mathrm{L}$. The UIE levels ranged from $22 \mu \mathrm{g} / \mathrm{L}$ to $534 \mu \mathrm{g} / \mathrm{L}$, and 29 women (19.6\%) had UIE below $150 \mu \mathrm{g} / \mathrm{L}^{15}$ The third study, published in 2014, evaluated 191 pregnant women aged 18 years and with gestational
Address for correspondence Mateus Dornelles Severo, Universidade Federal de Santa Maria, Avenida Roraima, 1000, prédio 22, 97105-340,

Santa Maria, RS, Brazil

(e-mail: mateusdsevero@gmail. com).
DOI https://doi.org/ 10.1055/s-0037-1608955. ISSN 0100-7203.
Copyright $\odot 2018$ by Thieme Revinter Publicações Ltda, Rio de Janeiro, Brazil

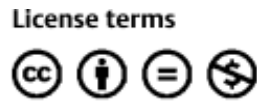


age up to 14 weeks, and it showed a median UIE of $137.7 \mu \mathrm{g} / \mathrm{L}$. Interestingly, in this study, 19 (9.9\%) pregnant women had UIE $>250 \mu \mathrm{g} / \mathrm{L}, 63$ (33\%) had UIE within the normal range $(150-250 \mu \mathrm{g} / \mathrm{L})$, and 109 (57.1\%) had UIE $<150 \mu \mathrm{g} / \mathrm{L}^{16}$

So, there is a part of the pregnant women population that is at risk of IDD and should probably receive supplementation. On the other hand, the majority of the general population and the pregnant women population, specifically, are iodine sufficient, in which case supplementation could induce adverse effects, such as Wolff-Chaikoff effect and neonatal hypothyroidism. $^{5}$ Besides that, the same ATA document suggests $500 \mu$ g per day as the upper limit of intake of iodine. Considering the Brazilian history of more than appropriate ingestion, supplementation with $150 \mu$ g per day may be enough to reach this ceiling, and the pregnant woman and the fetus may be exposed to the effects of excess iodine. Another limiting factor is that UIE, while being an extremely useful tool for assessing the adequacy of iodine in different populations, does not seem to be a good test for evaluating individuals. Variation in UIE concentrations is to be expected, when there is day-to-day and within-day variation in iodine intake, especially in iodinesufficient areas. Due to diurnal variations, random spot UIE concentration measurement is unlikely to precisely determine the proportion of a population that has a UIE median concentration $<50 \mu \mathrm{g} / \mathrm{L}$, which indicates iodine deficiency; the data can only be used to describe the central tendency and the dispersion of UIE concentrations for a particular population. ${ }^{17}$

Lastly, virtually all evidence associating mild to moderate iodine deficiency during gestation with subclinical neurological deficiencies in offspring, such as IQ reduction, comes from observational studies. ${ }^{18}$ To date, no clinical trial has demonstrated that iodine supplementation during gestation is capable of ameliorating any robust fetal-maternal outcome and only surrogate endpoints (thyroid volume, thyroglobulin levels) were evaluated. ${ }^{19}$

Therefore, we can conclude that the routine supplementation of iodine for every Brazilian pregnant woman is an intervention that needs to be better evaluated. Perhaps, some pregnant women from historically deficient areas of iodine and without access to iodized salt, as well as some other women with restrictive dietary patterns in salt, grains and dairy products, may benefit from iodine supplementation because they present a greater risk of severe deficiency, situation in which there is evidence that supplementation is effective in preventing severe outcomes, such as cretinism. ${ }^{20}$ However, efforts are needed to locate this profile of pregnant women within a country with extensive territory and great cultural diversity, such as Brazil, and to provide appropriate supplementation. $^{21}$

\section{Conflicts to Interest}

Authors declare no conflicts of interest.

\section{References}

1 Glinoer D. The importance of iodine nutrition during pregnancy. Public Health Nutr 2007;10(12A):1542-1546. Doi: 10.1017/ S1368980007360886
2 Andersson M, Aeberli I, Wüst N, et al. The Swiss iodized salt program provides adequate iodine for school children and pregnant women, but weaning infants not receiving iodine-containing complementary foods as well as their mothers are iodine deficient. J Clin Endocrinol Metab 2010;95(12):5217-5224. Doi: 10.1210/jc.2010-0975

3 Andersson M, de Benoist B, Rogers L. Epidemiology of iodine deficiency: Salt iodisation and iodine status. Best Pract Res Clin Endocrinol Metab 2010;24(01):1-11. Doi: 10.1016/j.beem.2009.08.005

4 Laurberg P, Cerqueira C, Ovesen L, et al. Iodine intake as a determinant of thyroid disorders in populations. Best Pract Res Clin Endocrinol Metab 2010;24(01):13-27. Doi: 10.1016/j.beem.2009.08.013

5 Novaes Júnior M, Biancalana MM, Garcia SA, Rassi I, Romaldini JH. Elevation of cord blood TSH concentration in newborn infants of mothers exposed to acute povidone iodine during delivery. J Endocrinol Invest 1994;17(10):805-808. Doi: 10.1007/BF03347781

6 Chanoine JP, Boulvain M, Bourdoux P, et al. Increased recall rate at screening for congenital hypothyroidism in breast fed infants born to iodine overloaded mothers. Arch Dis Child 1988;63(10): $1207-1210$

7 Alexander EK, Pearce EN, Brent GA, et al. 2017 Guidelines of the American Thyroid Association for the diagnosis and management of thyroid disease during pregnancy and the postpartum. Thyroid 2017;27(03):315-389. Doi: 10.1089/thy.2016.0457

8 Ministry of Health. Department of Health Care. [Technical Manual and Operational Pro-Iodine: National Program for Prevention and Control of Iodine Deficiency Disorders]. Brasília, DF: Ministry of Health; 2007. http://www.unicef.org/brazil/pt/iodo_manual.pdf. Accessed February 5, 2017

9 Federal Law n. 6,150 of 1974 December 3: provides for mandatory iodination of salt for human consumption, its control by health authorities and other measures. http://www.planalto.gov.br/ccivil_03/leis/L6150.htm. Accessed February 5, 2017

10 Ministério da Saúde. Agência Nacional de Vigilância Sanitária. Resolução RDC n. 32, de 25 de fevereiro de 2003. Dispõe sobre o teor de iodo no sal destinado ao consumo humano e dá outras providências. http://portal.anvisa.gov.br/documents/10181/2718376/RDC 32_2003_COMP.pdf/834699ff-bc93-427d-8db2-44ac508db032. Accessed February 5, 2017

11 Knobel M, Medeiros-Neto G. [Disorders associated to chronic iodine deficiency]. Arq Bras Endocrinol Metabol 2004;48(01): 53-61. Doi: 10.1590/S0004-27302004000100007

12 Ministério da Saúde. Secretaria de Atenção à Saúde. Departamento de Atenção Básica. Coordenação-Geral de Alimentação e Nutrição. XIV Reunião Ordinária da Comissão Interinstitucional para prevenção e Controle dos Distúrbios por Deficiência de Iodo. Brasília, DF: Ministério da Saúde; 2016. http://189.28.128.100/ dab/docs/portaldab/documentos/14_reuniao_iodo.pdf. Accessed August 8, 2017

13 Campos RdeO, Barreto IdosS, Maia LRJ, et al. Iodine nutritional status in Brazil: a meta-analysis of all studies performed in the country pinpoints to an insufficient evaluation and heterogeneity. Arch Endocrinol Metab 2015;59(01):13-22. Doi: 10.1590/ 2359-3997000000004

14 Barca MF, Knobel M, Tomimori E, Cárdia MS, Zugaib M, MedeirosNeto G. Aspectos ultra-sonográficos e prevalência da tireoidite pós-parto em gestantes sem disfunção tireóidea atendidas em hospital público de São Paulo. Arq Bras Endocrinol Metabol 2001; 45:180-189. Doi: 10.1590/S0004-27302001000200010

15 Soares R, Vanacor R, Manica D, et al. Thyroid volume is associated with family history of thyroid disease in pregnant women with adequate iodine intake: a cross-sectional study in southern Brazil. J Endocrinol Invest 2008;31(07):614-617. Doi: 10.1007/BF03345612

16 Ferreira SM, Navarro AM, Magalhães PK, Maciel LM. Iodine insufficiency in pregnant women from the State of São Paulo. Arq Bras Endocrinol Metabol 2014;58(03):282-287. Doi: 10.1590/00042730000002979 
17 Soldin OP. Controversies in urinary iodine determinations. Clin Biochem 2002;35(08):575-579. Doi: 10.1016/S0009-9120(02) 00406-X

18 Bath SC, Steer CD, Golding J, Emmett P, Rayman MP. Effect of inadequate iodine status in UK pregnant women on cognitive outcomes in their children: results from the Avon Longitudinal Study of Parents and Children (ALSPAC). Lancet 2013;382 (9889):331-337. Doi: 10.1016/S0140-6736(13)60436-5

19 Glinoer D, De Nayer P, Delange F, et al. A randomized trial for the treatment of mild iodine deficiency during pregnancy: maternal and neonatal effects. J Clin Endocrinol Metab 1995;80(01): 258-269. Doi: 10.1210/jcem.80.1.7829623

20 Boyages SC, Halpern JP, Maberly GF, et al. A comparative study of neurological and myxedematous endemic cretinism in western China. J Clin Endocrinol Metab 1988;67(06):1262-1271. Doi: 10.1210/jcem-67-6-1262

21 Villagelin D, Romaldini JH, Comarella AP, et al. Prenatal vitamin compounds available in brazil are not suitable for adequate iodine supplementation of pregnant women. Thyroid 2016;26(02):322. Doi: $10.1089 /$ thy.2015.0462 